\title{
Cytoadherence and Genotype of Plasmodium falciparum Strains from Symptomatic Children in Franceville, Southeastern Gabon
}

\author{
Fousseyni S. Touré, PhD; Odile Ouwe-Missi-Oukem-Boyer, PhD; \\ Jérôme Mezui-Me-Ndong, MS; Guy Roger Ndong-Atome, PhD student; \\ Ulrick Bisvigou, MD; Dominique Mazier, MD, PhD; and Sylvie Bisser, MD, PhD
}

\begin{abstract}
Background: Plasmodium falciparum causes severe clinical manifestations by sequestering parasitized red blood cells (PRBC) in the microvasculature of major organs such as the brain. This sequestration results from PRBC adherence to vascular endothelial cells via erythrocyte membrane protein I, a variant parasite surface antigen.
\end{abstract}

Objective: To determine whether $P$. falciparum multiple genotype infection (MGI) is associated with stronger PRBC cytoadherence and greater clinical severity.

Methods: Nested polymerase chain reaction was used to genotype $P$. falciparum isolates from symptomatic children and to distinguish between single genotype infection (SGI) and MGI. PRBC cytoadhesion was studied with cultured human lung endothelial cells.

Results: Analysis of two highly polymorphic regions of the merozoite surface antigen (MSP)-I and MSP-2 genes and a dimorphic region of the erythrocyte binding antigen- 175 gene showed that $21.4 \%$ and $78.6 \%$ of the 42 children had SGI and MGI, respectively. It also showed that 37 (89\%) of the 42 PRBC samples expressed MSP-I allelic family KI. Cytoadherence values ranged from 58 to $18 \mathrm{II}$ $\mathrm{PRBC} / \mathrm{mm}^{2}$ of human lung endothelial cells monolayer in SGI and from 5 to $5744 \mathrm{PRBC} / \mathrm{mm}^{2}$ in $\mathrm{MGl}$. MGI was not associated with higher cytoadherence values or with more severe malaria.

Conclusions: These results suggested that infection of the same individual by multiple clones of $P$. falciparum does not significantly influence PRBC cytoadherence or disease severity and confirmed the predominance of the MSP-I KI genotype in southeastern Gabon.

\section{Keywords: Malaria, Plasmodium falciparum, Cytoadherence, Merozoite surface antigen,} erythrocyte membrane protein I, multiple genotype infection

\section{P} malaria and kills up to 3 million people every year, mostly children in sub-Saharan Africa. ${ }^{1}$ It is unclear why some children and other non-immune hosts die while others remain asymptomatic or develop uncomplicated illness. ${ }^{2}$ P. falciparum-parasitized red blood cells (PRBC) can adhere to host endothelial cells, leading to mechanical blockade of microvessels, as well as cytokine secretion and modification of the $\mathrm{T}$ cell repertoire. ${ }^{3}$ PRBC sequestration obstructs capillaries and venules through various mechanisms, including cytoadherence, agglutination, rosetting and reduced red blood cell deformability. ${ }^{4,5} P$. falciparum erythrocyte membrane protein-1 (PfEMP-1) is the surface antigen variant that is the best characterized. It is expressed on PRBCs and is responsible for their adhesion to host endothelial cell receptors. PRBC cytoadherence in the microvasculature of organs, such as the brain and lungs is modulated by platelets ${ }^{6,7}$ and mediated by endothelial cell-surface receptors such as thrombospondin, CD36, intracellular adhesion molecule-1, vascular cellular adhesion molecule-1, CD31, integrins and hyaluronic acid. ${ }^{8}$ PRBC adhesion to endothelial cell receptors can induce (1) over-production of various inflammatory cytokines, such as interferon- $\gamma$, tumor necrosis factor- $\alpha$, transforming growth factor- $\beta$, interleukin-1 (IL-1), IL-6, IL-10 and IL-18 by endothelial cells, $, 3,7$ (2) phosphorylation and activation of 
endothelial cell cytosketal proteins such as cortactin, which increases junctional permeability through cytoskeleton changes, ${ }^{9}$ and (3) caspase activation and apoptosis. ${ }^{10}$

Most studies of interactions between PRBC and endothelial cell receptors have been done in vitro. Static and flow-based cytoadhesion assays have given useful information on host-parasite interactions, but few relevant data are available on P. falciparum multiple genotype infection (MGI) (co-infection by more than one parasite line). It has been proposed that initial binding of one parasite line may facilitate the adhesion of co-infecting parasite lines, and that initial binding of one clone reinforces $\mathrm{PRBC}$ sequestration by altering the endothelial cell surface. ${ }^{11}$

Human lung endothelial cells (HLEC) are a useful co-culture model for studying the pathophysiology of $P$. falciparum malaria in vitro ${ }^{12}$ and have been used to determine the cytoadherence and rosette phenotypes of $P$. falciparum isolates from Thailand. ${ }^{13}$ In this study, we used this model to investigate the cytoadherence of $P$. falciparum strains freshly isolated from symptomatic children and to identify possible relationships between MGI, cytoadherence and disease severity.

\section{Materials and Methods}

Patients

The study was conducted in the pediatric wards at Hôpital Amissa Bongo and Hôpital de l'Amitié Sinogabonaise in Franceville (Haut Ogooué province, Gabon) between July and November 2004. The study was approved by the Centre International de Recherches Médicales de Franceville Ethics Committee and by the Gabonese Ministry of Health. Children with symptoms of acute malaria were enrolled after informed consent of their parents or guardians was obtained. Clinical status was classified using the World Health Organization criteria. ${ }^{14}$ Malaria was diagnosed using the thick-film method. Blood was collected in sterile EDTA tubes for culture when it contained more than 5000 P. falciparum asexual forms $/ \mu \mathrm{L}$. The children were treated according to local guidelines, and care was provided until hospital discharge.

\section{Parasites}

Thick and thin peripheral blood films were stained with Giemsa and examined by microscope. Parasite load is expressed as the number of asexual forms of P. falciparum $/ \mu \mathrm{L}$ of blood, assuming an average leukocyte count of $8000 / \mu \mathrm{L}$. Parasites from children with more than 5000 asexual forms $/ \mu \mathrm{L}$ of blood were selected for ex vivo cultivation. White blood cells were separated using Ficoll gradient and 4 washes with RPMI 1640 medium and PRBC were cultured immediately, as previously described. ${ }^{15}$ RPMI 1640 medium was supplemented with $8.3 \mathrm{~g} / \mathrm{L}$ HEPES, $2.1 \mathrm{~g} / \mathrm{L}$ sodium bicarbonate, $0.1 \mu \mathrm{g} / \mathrm{mL}$ gentamicin, $1 \mu \mathrm{g} / \mathrm{mL}$ Fungizone, 2 $\mathrm{g} / \mathrm{L}$ of D-glucose and $0.4 \%$ Albumax II (Invitrogen Cergy Pontoise, France). All experiments were performed during the first cycle of in vitro parasite growth. Parasite growth to the schizont form was checked by examination of Giemsa-stained thin blood films after 24 or 48 hours. Mature parasites were collected and counted after enrichment by gelatine flotation after 24 to 48 hours. ${ }^{10,16}$ A schizont suspension was prepared using RPMI 1640 medium, pH 6.8.

\section{Culture of HLECS}

HLEC were derived from one batch, as described elsewhere. ${ }^{12}$ HLEC were cultured in flasks (Corning, NY) at $37^{\circ} \mathrm{C}$ with $5 \%$ $\mathrm{CO}_{2}$ using medium 199 containing 10\% (vol/vol) fetal calf serum, 50 units $/ \mathrm{mL}$ of penicillin-streptomycin and $0.25 \mu \mathrm{g}$ of Fungizone (Invitrogen). The cells were used at passage 8 and were characterized for their expression of von Willebrand factor, ICAM-1, VCAM-1, CD31, CD36, E/P-selectin and chondroitin sulfate $\mathrm{A}$, as previously published. ${ }^{10}$ The fact that HLEC express a multitude of potential PRBC host receptors opens the way for a follow-up study where the relative importance of these receptors for PRBC adhesion is studied in more detail (e.g., by using antibodies to block PRBC adhesion to specific receptors). HLEC were seeded at a density of 0.5 to $1 \times 10^{4}$ cells $/ \mathrm{cm}^{2}$ and grown until confluence was achieved.

\section{Cytoadherence Assay}

Endothelial cells were subcultured at a density of 3,000 cells/well in 8-well tissue culture plates and cultivated for 24 to 48 hours under standard conditions to reach confluence. The cells were then either used in a cytoadherence assay directly or kept at $4^{\circ} \mathrm{C}$ in $300 \mu \mathrm{L}$ of phosphate buffered saline (PBS) (for a maximum of 2 months) after fixation for 20 minutes at $37^{\circ} \mathrm{C}$ with $2 \%$ paraformaldehyde. For binding tests, $300 \mu \mathrm{L}$ of the schizont suspension at $5 \%$ hematocrit were deposited onto cell monolayers in duplicate and incubated for 1 hour at $37^{\circ} \mathrm{C}$. After removal of non-adherent schizonts with 3 washes in PBS, the preparation was fixed for 20 minutes with $2 \%$ glutaraldehyde, rinsed with PBS and stained with Giemsa. Cytoadherence was expressed as the number of PRBCs adhered in $\mathrm{mm}^{2}$ of cultured HLEC.

\section{DNA Amplification for P. falciparum Genotyping}

$P$. falciparum DNA templates were extracted using $100 \mu \mathrm{L}$ of each peripheral blood sample as previously described. ${ }^{17,18}$ Genotypes of the parasite populations were analyzed by nested polymerase chain reaction (PCR). Block 2 of merozoite surface antigen (MSP)-1 and block 3 of MSP-2 were amplified as previously reported. ${ }^{19}$ Erythrocyte binding antigen (EBA)-175 genotype was also determined as described elsewhere. ${ }^{20}$ After the nested-PCR amplifications, $10 \mu \mathrm{L}$ of each amplification product were analyzed by electrophoresis on a $1.5 \%$ agarose gel. The gel was stained with ethidium bromide, and the DNA visualized under ultraviolet light.

\section{Statistical Analysis}

Data were analyzed using the $\chi^{2}$ and Student's $t$-tests. The Mann-Whitney $U$ test was also employed when variable distribution was not normalized. Associations between quantitative variables were assessed by the Spearman's rank test of correlation. For all tests, $P$ values $<0.05$ were considered significant. 
Table 1. Parasitological, biological and clinical characteristics of Plasmodium falciparum (Pf) from single genotype infections.

\begin{tabular}{|c|c|c|c|c|c|c|}
\hline \multirow[b]{2}{*}{$\mathrm{Pf}$ isolates } & \multirow[b]{2}{*}{$\begin{array}{l}\text { Number of } \\
\text { schizont }^{\star}\end{array}$} & \multirow[b]{2}{*}{$\begin{array}{l}\text { Cytoadherence } \\
\text { PRBC/mm²HLEC }\end{array}$} & \multirow[b]{2}{*}{$\begin{array}{l}\text { Clinical } \\
\text { signs }\end{array}$} & \multicolumn{3}{|c|}{ PCR } \\
\hline & & & & EBA-175 & MSP-1 & MSP-2 \\
\hline D3 & 47025 & 1748 & & FCR-3 & $\mathrm{k} 1$ & - \\
\hline F37 & 80190 & 197 & $\mathrm{~h}$ & CAMP & k1 & FC27 \\
\hline F42 & 40095 & 1561 & $\mathrm{~h}$ & FCR-3 & k1 & 3D7 \\
\hline F5 & 47025 & 1741 & & FCR-3 & $\mathrm{k} 1$ & 3D7 \\
\hline F51 & 37620 & 1811 & & FCR-3 & k1 & 3D7 \\
\hline F52 & 23513 & 603 & & FCR-3 & k1 & FC27 \\
\hline F58 & 3762 & 58 & & FCR-3 & k1 & 3D7 \\
\hline F61 & 28215 & 874 & & FCR-3 & k1 & FC27 \\
\hline F68 & 10890 & 600 & & FCR-3 & k1 & 3D7 \\
\hline
\end{tabular}

* Number of schizont $x 10^{3}$.

h, hyperparasitemia; EBA-175, erythrocyte binding antigen 175 kiloDalton; HLEC; human lung endothelial cells; MSP, merozoite surface protein; PRBC, parasitized red blood cells.

\section{Results}

\section{Patients}

We studied 42 children ranging in age from 1 to 10 years who were symptomatic with $P$. falciparum. The children were divided into two groups based on the P. falciparum MSP-1, MSP-2 and EBA-175 genotypes: 9 children (21.4\%) had single genotype infection (SGI) and the other 33 children (78.6\%) had MGI. Two (22.2\%) of the 9 children with SGI had severe malaria diagnosed solely on the basis of high-level parasitemia ( $\geq 20 \%)$. Nine $(27.2 \%)$ of the 33 children with MGI had severe malaria. Four of these children had neurological signs (3 with altered consciousness; 1 with cerebral malaria), one had isolated severe anemia $(4 \mathrm{~g} \mathrm{Hb} / \mathrm{dL})$ and four had only high-level parasitemia (tables 1 and 2).

\section{Parasites}

Parasitemia ranged from $0.4 \%$ to $39 \%$. The numbers of schizonts in the specimens used for cytoadherence assays ranged from $3762 \times 10^{3}$ to $80,190 \times 10^{3}$ in SGI and from $396 \times 10^{3}$ to 81,972 $\times 10^{3}$ in MGI (tables 1 and 2); the respective mean numbers of schizonts were $35,370 \times 10^{3}$ and $30,818 \times 10^{3}$.

\section{Genetic Characteristics of P. falciparum Isolates}

MSP-1, MSP-2 and EBA-175 fragments that could be assigned to specific allelic families were used to characterize parasite subpopulations. Of the 42 P. falciparum isolates, 7 $(16.7 \%)$ comprised at least three different genotypes, 26 (61.9\%) with two genotypes and the remaining 9 (21.4\%) with a single genotype. In MGI, the family distributions were 23/33 (69.7\%) of FCR3, 15/33 (45.4\%) of CAMP for the EBA-175 locus; $29 / 33$ (87.9\%) of Ro33, 28/33 (84.8\%) of K1, 15/33 (45.4\%) Mad20 for MSP-1; 21/26 (80.7\%) of
FC27 and 13/26 (50\%) of 3D7 for MSP-2. In SGI, all parasites were genotype K1 for the MSP-1 locus; $87.5 \%$ of FCR3, $12.5 \%$ of CAMP for EBA-175; $62.5 \%$ of 3D7 and $37.5 \%$ of $\mathrm{FC} 27$ for MSP-2. In total, the allelic family distributions were $37 / 42$ (89\%) of K1, 30/42 (71\%) of Ro33, $15 / 42(36 \%)$ of Mad20 for MSP-1; 16/42 (39\%) of CAMP, $31 / 42$ (74\%) of FCR3 for EBA-175 and 18/42 (43\%), 24/42 (57\%) for the MSP-2 locus.

\section{Cytoadherence}

All the PRBC samples adhered to HLEC (figure 1), with values ranging from 58 to $1811 \mathrm{PRBC} / \mathrm{mm}^{2}$ in SGI (figure 2) and from 5 to $5744 \mathrm{PRBC} / \mathrm{mm}^{2}$ in MGI (figure 3). Thirty-five $(83.3 \%)$ of the 42 PRBC samples gave values above 200 $\mathrm{PRBC} / \mathrm{mm}^{2}$ (arbitrary cutoff); six of the remaining seven samples were from subjects with MGI. This cutoff was not predictive of the severity of malaria (tables 1 and 2). Likewise, the schizont count was not related to the cytoadherence value of the corresponding sample. Several PRBC samples from patients with high-level parasitemia had very low cytoadherence values (see sample F63 for example, table 2). The performance of our adhesion assay was not significantly affected by the use of fixed HLEC within 2 months (figure 4).

\section{Relationship between Cytoadherence, MGI and Severe Malaria}

There was no significant difference in the mean cytoadherence values between PRBC from patients with SGI (1021 $\left.\mathrm{PRBC} / \mathrm{mm}^{2}\right)$ and those with MGI $\left(1028 \mathrm{PRBC} / \mathrm{mm}^{2}\right)(P=0.55)$. Likewise, there was no relationship between severe malaria and either MGI $(P=1.00)$ or the cytoadherence value $(P=0.92)$. 
Table 2. Parasitological, biological and clinical characteristics of Plasmodium falciparum (Pf) from multiple genotype infections.

\begin{tabular}{|c|c|c|c|c|c|c|}
\hline \multirow[b]{2}{*}{ Pf isolates } & \multirow[b]{2}{*}{$\begin{array}{l}\text { Number of } \\
\text { schizont }^{\star}\end{array}$} & \multirow[b]{2}{*}{$\begin{array}{l}\text { Cytoadherence } \\
\text { PRBC/mm²HLEC }\end{array}$} & \multirow[b]{2}{*}{$\begin{array}{l}\text { Clinical } \\
\text { signs }\end{array}$} & \multicolumn{3}{|c|}{ PCR } \\
\hline & & & & EBA-175 & MSP-1 & MSP-2 \\
\hline D1 & - & 580 & & FCR3 & K1/Ro33 & $\mathrm{FC} 27$ \\
\hline $\mathrm{F} 1$ & 29122 & 5744 & & FCR3 & K1/Ro33/Mad20 & 3D7/FC27 \\
\hline $\mathrm{F} 17$ & 6584 & 36 & & FCR3 & K1/Ro33 & FC27 \\
\hline F26 & 14108 & 230 & a & FCR3 & K1/Ro33/Mad20 & $\mathrm{FC} 27$ \\
\hline F28 & 3168 & 341 & & FCR3 & K1/Ro33 & $3 \mathrm{D} 7$ \\
\hline $\mathrm{F} 29$ & 55688 & 1169 & & CAMP & Ro33/Mad20 & - \\
\hline F3 & 14642 & 216 & $p$ & FCR3/CAMP & K1/Ro33 & 3D7/FC27 \\
\hline F30 & 29700 & 3122 & & CAMP & K1/Ro33 & 3D7/FC27 \\
\hline F31 & 71280 & 937 & $h, p$ & CAMP & Ro33/Mad20 & $\mathrm{FC} 27$ \\
\hline F32 & 75240 & 5619 & $\mathrm{~h}$ & CAMP & K1/Ro33/Mad20 & 3D7/FC27 \\
\hline F33 & 18810 & 513 & & CAMP & K1/Ro33 & 3D7/FC27 \\
\hline F34 & 53460 & 3012 & & CAMP & K1/Ro33/Mad20 & FC27 \\
\hline F36 & 1980 & 6 & & FCR3 & K1/Ro33 & FC27 \\
\hline F38 & 2475 & 250 & & FCR3 & K1/Rо33 & FC27 \\
\hline F39 & 396 & 63 & & CAMP & K1/Ro33/Mad20 & 3D7 \\
\hline $\mathrm{F} 41$ & 23513 & 215 & & FCR3/CAMP & K1/Ro33 & 3D7/FC27 \\
\hline $\mathrm{F} 43$ & 9405 & 212 & & FCR3/CAMP & K1/Ro33 & - \\
\hline $\mathrm{F} 44$ & 9405 & 212,0 & & FCR3/CAMP & Ro33/Mad20 & $3 \mathrm{D} 7$ \\
\hline F45 & 80190 & 1793 & $\mathrm{~h}$ & FCR3/CAMP & K1/Ro33/Mad20 & 3D7 \\
\hline $\mathrm{F} 47$ & 23513 & 235 & & FCR3 & Ro33/Mad20 & $\mathrm{FC} 27$ \\
\hline $\mathrm{F} 48$ & 24008 & 998 & & FCR3 & K1/Ro33/Mad20 & $\mathrm{FC} 27$ \\
\hline $\mathrm{F} 49$ & 6683 & 687 & & FCR3 & K1/Ro33 & - \\
\hline F50 & 51728 & 613 & & FCR3 & K1/Mad20 & FC27 \\
\hline F53 & 80190 & 592 & $\mathrm{~h}$ & FCR3 & K1/Ro33 & FC27 \\
\hline F54 & 23513 & 610 & & FCR3 & K1/Ro33 & - \\
\hline F55 & 18810 & 1873 & & CAMP & $\mathrm{K} 1$ & 3D7/FC27 \\
\hline F59 & 9603 & 7 & & FCR3 & K1/Ro33 & FC27 \\
\hline F60 & 11286 & 13 & & CAMP & K1/Mad20 & - \\
\hline F62 & 11880 & 437 & $p$ & FCR3 & K1/Ro33 & $3 \mathrm{D} 7$ \\
\hline F63 & 56430 & 5 & $\mathrm{~h}$ & FCR3 & Ro33/Mad20 & FC27 \\
\hline F64 & 23513 & 1561 & & FCR3 & K1/Ro33/Mad20 & - \\
\hline F67 & 1782 & 332 & & CAMP & K1/Ro33 & 3D7/FC27 \\
\hline F69 & 81972 & 1686 & $\mathrm{~h}, \mathrm{c}, \mathrm{a}$ & FCR3 & K1/Ro33 & - \\
\hline
\end{tabular}

${ }^{*}$ Number of schizont $\times 10^{3}$.

a, anemia; c, coma; h, hyperparasitemia; p, prostration; EBA-175, erythrocyte binding antigen 175 kiloDalton; HLEC; human lung endothelial cells; MSP, merozoite surface protein; PRBC, parasitized red blood cells; PCR, polymerase chain reaction. 


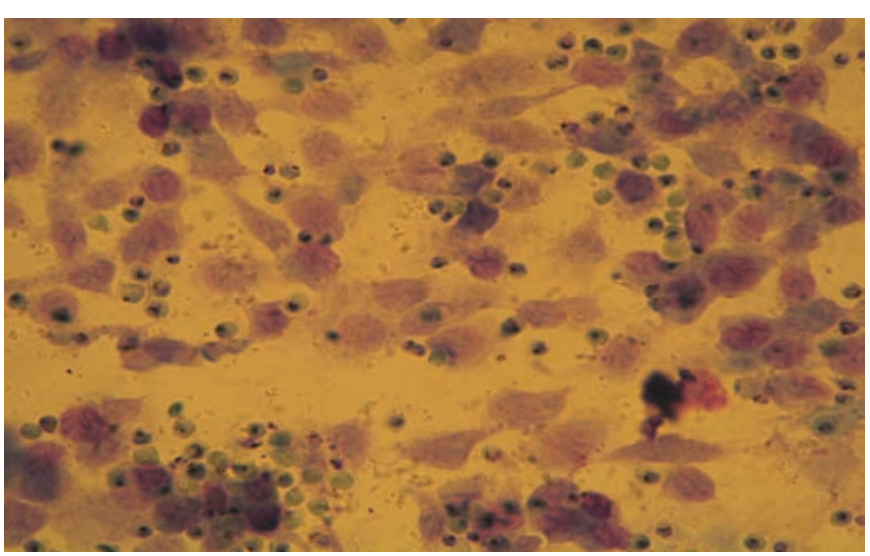

Figure 1. Cytoadherence of Plasmodium falciparum parasitized red blood cells (PRBC) to human lung endothelial cells (HLEC): 5619 PRBC/mm² HLEC.

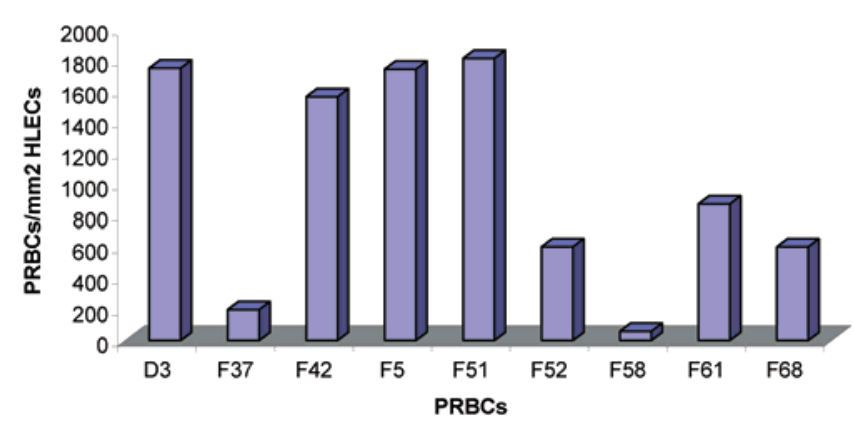

Figure 2. Cytoadherence profiles of Plasmodium falciparum single genotype infection isolates.

Relationship between Genotype K1 and Severe Malaria

The K1 genotype was observed in $9(82 \%)$ of 11 individuals with severe malaria and in $28(90 \%)$ of 31 individuals with uncomplicated malaria $(P=0.8)$. Therefore, the $\mathrm{K} 1$ genotype is not associated with severe malaria.

\section{Discussion}

The disappearance of mature PRBC from peripheral blood concomitantly with their sequestration in the microvasculature of major organs, such as the brain, plays a key role in the pathogenesis of $P$. falciparum malaria. ${ }^{21}$ Here we investigated the cytoadherence status of $P$. falciparum strains from symptomatic children and sought possible relationships between MGI, cytoadherence and disease severity.

More than three-quarters of the patients had MGI, confirming the extensive polymorphism of $P$. falciparum in southeastern Gabon.22-24 However, it has been demonstrated that some clones of $P$. falciparum are able to disappear and reappear in the peripheral blood from infected individuals within as little as 2 hours. ${ }^{25}$ Due to the fluctuation of parasite density and complexity, a single peripheral blood sampling does not reflect the full complexity of the parasite populations harbored by a given individual. ${ }^{26}$ Thus, it is possible that the numbers of MGI specimens are underestimated in our study for two reasons: first, the blood samples were collected only one time and second, our PCR method may have failed in detecting minority parasites in MGI or previously sequestered parasites that were not present in the peripheral blood at the time of sampling. Jafari et $\mathrm{al}^{25}$ found that $95 \%$ of patients had MGI and showed that minority parasites representing as little as $0.4 \%$ of total parasitemia can be detected via quantitative PCR assay. We found no association between MGI and severe disease. This is in contrast to another study of Gabonese children, which demonstrated that clinical malaria attacks were associated with increased complexity of infection. ${ }^{23}$ However, the reverse has also been observed in Senegalese, Tanzanian and Papua New Guinean children. ${ }^{27-29}$

In our study, three genetic loci were amplified by nested PCR to discriminate P. falciparum SGI and MGI. The Ro33, K1, FC27 and FCR3 genotypes of the MSP-1, MSP-2 and EBA-175 genes, respectively, were predominant in MGI. By contrast, in SGI all the parasites were the K1 genotype. This may be due to the fact that K1 was the predominant MSP-1 genotype. The most prevalent EBA-175 genotype in SGI was FCR3 genotype. This result is therefore consistent with our previously reported data. ${ }^{30}$ Overall, our study demonstrated the predominance of the allelic family K1 of MSP-1 locus clearly, confirming data reported elsewhere. 31,32 However, no significant association was found between the occurrence of the K1 genotype and severe malaria; K1 was observed in $82 \%$ and $90 \%$ PRBC from individuals with severe and uncomplicated malaria, respectively. Nevertheless, possible differences within $\mathrm{K} 1$ or other allelic families between individuals with mild versus severe malaria remain to be investigated. For example, in French Guiana, it has been demonstrated that a specific MSP-1 allele (B-K1) bearing a specific variant gene (var-D) has been linked to severe malaria. ${ }^{33}$ In Dienga, a village situated in southeastern Gabon approximately $200 \mathrm{~km}$ from Franceville where the present study was carried out, the K1 and Mad20 families of MSP-1 were predominantly found in symptomatic individuals compared to asymptomatics. ${ }^{23}$ By contrast, in Nigeria it has been shown that the presence of the K1 and MAD20 alleles was significantly associated with asymptomatic malaria, and consequently, a reduced risk of developing the symptomatic disease. ${ }^{34}$ Ranjit et $\mathrm{al}^{35}$ have also shown that Mad20/MSP-1 and 3D7/MSP-2 alleles were over-represented in severe malaria cases in Orissa (India). Finally, it has also been reported that clinical malaria was associated with 3D7/MSP-2 in some African endemic areas. . $^{36,37}$ Together these results demonstrate that the distribution of $P$. falciparum genotypes according to clinical severity differs across geographic regions.

Most PRBC samples tested in this study showed a high level of cytoadherence to HLEC. However, there were significant differences in levels of cytoadhesion between individual PRBC strains from SGI or MGI, suggesting differences in parasite encoding ligands such as PfEMP1, the most important variant surface antigen. ${ }^{38}$ PRBCs continuously switch expression of PfEMP1 proteins and thereby evade immune destruction. Hence, a single PRBC only expresses a single variant surface antigen type at a given time and can switch to another variant surface antigen at any time, 
regardless of the variant surface antigen expressed by other PRBC, whether they are infected with genotypically identical parasites or not. Furthermore, some single variant surface antigen types may have multiple adhesion domains. Consequently, both MGI and SGI are composed of parasite populations expressing a mixture of distinct PfEMP1 proteins that bind to different host receptors. This might explain why MGI was not associated with higher cytoadherence values in our study.

Cytoadhesion involves as many as 11 types of endothelial cell receptors ${ }^{11}$ and the HLEC used in the study co-expressed CD36 and ICAM-1, the two major receptors for PfEMP-1 ligand, among others. CD36 and ICAM-1 act synergistically in mediating PRBC binding to endothelial cells co-expressing both receptors. ${ }^{39,40}$ Although the binding phenotypes of PRBC were not assessed, our results are consistent with data reported by Newbold et $\mathrm{al}^{41}$ showing that almost all PRBC isolates assessed in their experiments bind in vitro to purified CD36 and most to ICAM-1. Nevertheless, much of the binding could have been due simply to CD36, which is an extremely common parasite adhesion trait. In this respect, it is of interest that the CIDR $\alpha$ domains of PfEMP1 proteins bind to CD36 despite the sequence divergence of these domains. ${ }^{42}$

In our study, no correlation was found between the levels of cytoadhesion of PRBC isolates and malaria severity. This result confirmed previous data reported elsewhere ${ }^{2}$ and reinforces the conclusion that coma is the only manifestation caused by cytoadhesion of PRBC to the brain vascular endothelium via variant surface antigen. ${ }^{43}$ Indeed, it has been documented that severe malaria is associated with expression of the variant surface antigen group $\mathrm{A},{ }^{44-46}$ group $\mathrm{B},{ }^{47}$ groups $\mathrm{A}$ or $\mathrm{B} / \mathrm{A},{ }^{48}$ groups A and B, ${ }^{49}$ and group D. ${ }^{33}$ Moreover, the postmortem analysis of the brain revealed that all coma cases did not have sequestered parasites in cerebral capillaries. ${ }^{50}$ There is also evidence suggesting that severe malaria is associated with expression of PfEMP1 variants that do not bind to CD36.51,52 Therefore, the lack of association between cytoadherence and disease severity observed in our study could be explained by the small number of patients with cerebral malaria. In future studies with a larger number of parasite isolates from individuals with cerebral malaria, it would be interesting to explore variant surface antigen expression patterns in relation to the parasite genotypes present and host endothelial cell binding phenotype.

In conclusion, our results suggested that PRBC avidity for HLECs is not influenced by the number of clones infecting a given individual. We also confirm the predominance of the K1 genotype at the MSP-1 locus in southeastern Gabon.

\section{Acknowledgments}

We are grateful to the children and their parents or guardians for participating in the study and to the staff of the pediatric wards at Hôpital Amissa Bongo and Hôpital de l'Amitié Sinogabonaise in Franceville.

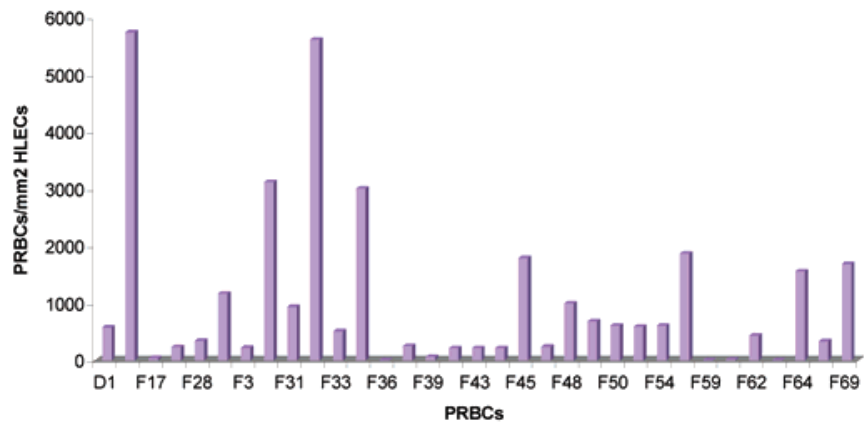

Figure 3. Cytoadherence profiles of Plasmodium falciparum multiple genotype infection isolates.

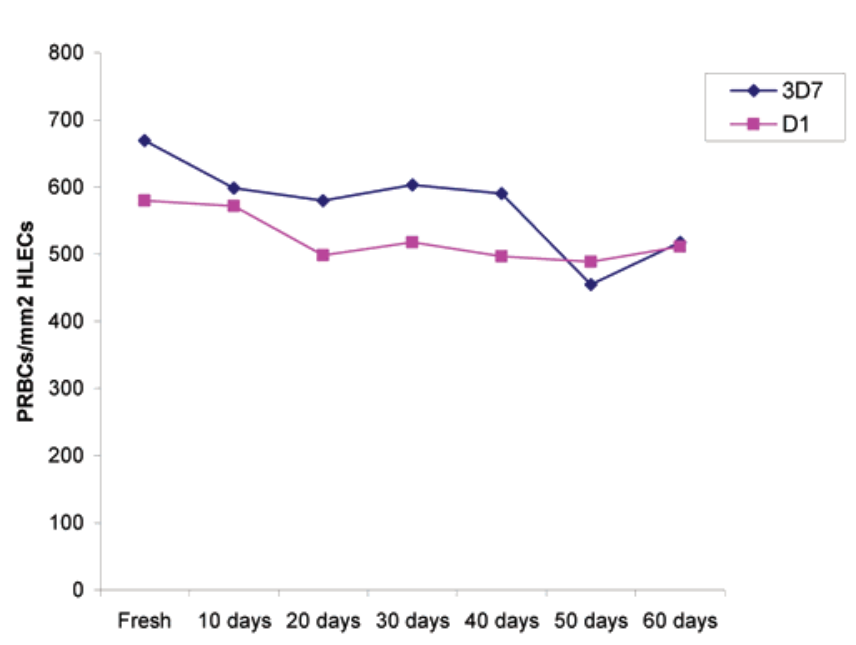

Figure 4. Comparative analysis of cytoadherence of Plasmodium falciparum 3D7 and field isolate (D1) using fresh or fixed human lung endothelial cells (HLEC).

\section{References}

1. Breman JG, Egan A, Keusch GT. The intolerable burden of malaria: a new look at the numbers. Am J Trop Med Hyg 2001;64:iv-vii.

2. Marsh K, Marsh VM, Brown J, Whittle HC, Greenwood BM. Plasmodium falciparum: the behavior of clinical isolates in an in vitro model of infected red blood cell sequestration. Exp Parasitol 1988;65:202-208.

3. Mazier D, Nitcheu J, Idrissa-Boubou M. Cerebral malaria and immunogenetics. Parasite Immunol 2000;22:613-623.

4. Pongponratn E, Turner GD, Day NP, Phu NH, Simpson JA Stepniewska K, Mai NT, Viriyavejakul P, Looareesuwan S, Hien TT, Ferguson DJ, White NJ. An ultrastructural study of the brain in fatal Plasmodium falciparum malaria. Am J Trop Med Hyg 2003;69:345-359.

5. Dondorp AM, Pongponratn E, White NJ. Reduced microcirculatory flow in severe falciparum malaria: pathophysiology and electron-microscopic pathology. Acta Trop 2004;89:309-317.

6. Wassmer SC, Combes V, Grau GE. Pathophysiology of cerebral malaria: role of host cells in the modulation of cytoadhesion. Ann N Y Acad Sci 2003;992:30-38.

7. Hunt NH, Grau GE. Cytokines: accelerators and brakes in the pathogenesis of cerebral malaria. Trends Immunol 2003;24:491-499.

8. Craig A, Scherf A. Molecules on the surface of the Plasmodium falciparum infected erythrocyte and their role in malaria pathogenesis and immune evasion. Mol Biochem Parasitol 2001;115:129-143. 
9. Adams S, Brown H, Turner G. Breaking down the blood-brain barrier: signaling a path to cerebral malaria? Trends Parasitol 2002;18:360-356.

10. Pino P, Vouldoukis I, Kolb JP, Mahmoudi N, Desportes-Livage I, Bricaire F, Danis M, Dugas B, Mazier D. Plasmodium falciparum - infected erythrocyte adhesion induces caspase activation and apoptosis in human endothelial cells. J Infect Dis 2003;187:1283-1290.

11. Chakravorty SJ, Craig A. The role of ICAM-1 in Plasmodium falciparum cytoadherence. Eur J Cell Biol 2005;84:15-27.

12. Muanza K, Gay F, Behr C, Scherf A. Primary culture of human lung microvessel endothelial cells: a useful in vitro model for studying Plasmodium falciparum-infected erythrocyte cytoadherence. Res Immunol 1996;147:149-163.

13. Traore B, Muanza K, Looareesuwan S, Supavej S, Khusmith S, Danis M, Viriyavejakul P, Gay F. Cytoadherence characteristics of Plasmodium falciparum isolates in Thailand using an in vitro human lung endothelial cells model. Am J Trop Med Hyg 2000;62:38-44.

14. Severe falciparum malaria. World Health Organization, Communicable Diseases Cluster. Trans R Soc Trop Med Hyg 2000;94:S1-S90

15. Trager W, Jensen JB. Human malaria parasites in continuous culture. Science 1976;193:673-675.

16. Goodyer ID, Johnson J, Eisenthal R, Hayes DJ. Purification of mature-stage Plasmodium falciparum by gelatine flotation. Ann Trop Med Parasitol 1994;88:209-211.

17. Mercereau-Puijalon O, Fandeur T, Bonnefoy S, Jacquemot C, Sarthou JL. A study of the genomic diversity of Plasmodium falciparum in Senegal. 2. Typing by the use of the polymerase chain reaction. Acta Trop 1991;49:293-304.

18. Ntoumi F, Contamin H, Rogier C, Bonnefoy S, Trape JF, Mercereau-Puijalon O. Age-dependent carriage of multiple Plasmodium falciparum merozoite surface antigen-2 alleles in asymptomatic malaria infections. Am J Trop Med Hyg 1995;52:81-88.

19. Snounou G, Zhu X, Siripoon N, Jarra W, Thaithong S, Brown $\mathrm{KN}$, Viriyakosol S. Biased distribution of $\mathrm{msp} 1$ and $\mathrm{msp} 2$ allelic variants in Plasmodium falciparum populations in Thailand. Trans R Soc Trop Med Hyg 1999;93:369-374.

20. Toure FS, Mavoungou E, Ndong JM, Tshipamba P, Deloron P. Erythrocyte binding antigen (EBA-175) of Plasmodium falciparum: improved genotype determination by nested polymerase chain reaction. Trop Med Int Health 2001;6:767-769.

21. Chen Q, Schlichtherle M, Wahlgren M. Molecular aspects of severe malaria. Clin Microbiol Rev 2000;13:439-450.

22. Ntoumi F, Rogier C, Dieye A, Trape JF, Millet P, Mercereau-Puijalon O. Imbalanced distribution of Plasmodium falciparum MSP-1 genotypes related to sickle-cell trait. Mol Med 1997;3:581-592.

23. Ntoumi F, Ngoundou-Landji J, Lekoulou F, Luty A, Deloron P, Ringwald P. Site-based study on polymorphism of Plasmodium falciparum MSP-1 and MSP-2 genes in isolates from two villages in Central Africa. Parassitologia 2000;42:197-203.

24. Aubouy A, Migot-Nabias F, Deloron P. Polymorphism in two merozoite surface proteins of Plasmodium falciparum isolates from Gabon. Malar J 2003;2:12.

25. Jafari S, Le Bras J, Bouchaud O, Durand R. Plasmodium falciparum clonal population dynamics during malaria treatment. J Infect Dis 2004;189:195-203.

26. Jafari-Guemouri S, Boudin C, Fievet N, Ndiaye P, Deloron P. Plasmodium falciparum genotype population dynamics in asymptomatic children from Senegal. Microbes Infect 2006;8:1663-1670.
27. Contamin H, Fandeur T, Rogier C, Bonnefoy S, Konate L, Trape JF, Mercereau-Puijalon O. Different genetic characteristics of Plasmodium falciparum isolates collected during successive clinical malaria episodes in Senegalese children. Am J Trop Med Hyg 1996;54:632-643.

28. Beck HP, Felger I, Huber W, Steiger S, Smith T, Weiss N, Alonso P, Tanner M. Analysis of multiple Plasmodium falciparum infections in Tanzanian children during the phase III trial of the malaria vaccine SPf66. J Infect Dis 1997; 175:921-926.

29. al-Yaman F, Genton B, Reeder JC, Anders RF, Smith T, Alpers MP. Reduced risk of clinical malaria in children infected with multiple clones of Plasmodium falciparum in a highly endemic area: a prospective community study. Trans R Soc Trop Med Hyg 1997;91:602-605.

30. Toure FS, Bisseye C, Mavoungou E. Imbalanced distribution of Plasmodium falciparum EBA-175 genotypes related to clinical status in children from Bakoumba, Gabon. Clin Med Res 2006;4:7-11.

31. Kun JF, Schmidt-Ott RJ, Lehman LG, Lell B, Luckner D, Greve B, Matousek P, Kremsner PG. Merozoite surface antigen 1 and 2 genotypes and rosetting of Plasmodium falciparum in severe and mild malaria in Lambarene, Gabon. Trans R Soc Trop Med Hyg 1998;92:110-114.

32. Missinou MA, Kun JF, Lell B, Kremsner PG. Change in Plasmodium falciparum genotype during successive malaria episodes in Gabonese children. Parasitol Res 2001;87:1020-1023.

33. Ariey F, Hommel D, Le Scanf C, Duchemin JB, Peneau C, Hulin A, Sarthou JL, Reynes JM, Fandeur T, Mercereau-Puijalon O. Association of severe malaria with a specific Plasmodium falciparum genotype in French Guiana. J Infect Dis 2001;184:237-241.

34. Amodu OK, Adeyemo AA, Ayoola OO, Gbadegesin RA, Orimadegun AE, Akinsola AK, Olumese PE, Omotade OO. Genetic diversity of the msp-1 locus and symptomatic malaria in south-west Nigeria. Acta Trop 2005;95:226-232.

35. Ranjit MR, Das A, Das BP, Das BN, Dash BP, Chhotray GP. Distribution of Plasmodium falciparum genotypes in clinically mild and severe malaria cases in Orissa, India. Trans R Soc Trop Med Hyg 2005;99:389-395.

36. Conway DJ, McBride JS. Population genetics of Plasmodium falciparum within a malaria hyperendemic area. Parasitology 1991;103:7-16

37. Babiker HA, Satti G, Walliker D. Genetic changes in the population of Plasmodium falciparum in a Sudanese village over a three-year period. Am J Trop Med Hyg 1995;53:7-15.

38. Sherman IW, Eda S, Winograd E. Cytoadherence and sequestration in Plasmodium falciparum: defining the ties that bind. Microbes Infect 2003;5:897-909.

39. Udomsangpetch R, Reinhardt PH, Schollaardt T, Elliott JF, Kubes P, Ho M. Promiscuity of clinical Plasmodium falciparum isolates for multiple adhesion molecules under flow conditions. J Immunol 1997;158:4358-4364.

40. McCormick CJ, Craig A, Roberts D, Newbold CI, Berendt AR. Intercellular adhesion molecule-1 and CD36 synergize to mediate adherence of Plasmodium falciparum-infected erythrocytes to cultured human microvascular endothelial cells. J Clin Invest 1997;100:2521-2529.

41. Newbold C, Warn P, Black G, Berendt A, Craig A, Snow B, Msobo M, Peshu N, Marsh K. Receptor-specific adhesion and clinical disease in Plasmodium falciparum. Am J Trop Med Hyg 1997;57:389-398.

42. Robinson BA, Welch TL, Smith JD. Widespread functional specialization of Plasmodium falciparum erythrocyte membrane protein 1 family members to bind CD36 analysed across a parasite genome. Mol Microbiol 2003;47:1265-1278. 
43. Newbold CI, Craig AG, Kyes S, Berendt AR, Snow RW, Peshu N, Marsh K. PfEMP1, polymorphism and pathogenesis. Ann Trop Med Parasitol 1997;91:551-557.

44. Bull PC, Berriman M, Kyes S, Quail MA, Hall N, Kortok MM, Marsh K, Newbold CI. Plasmodium falciparum variant surface antigen expression patterns during malaria. PLoS Pathog 2005; 1:e26.

45. Nielsen MA, Staalsoe T, Kurtzhals JA, Goka BQ, Dodoo D, Alifrangis M, Theander TG, Akanmori BD, Hviid L. Plasmodium falciparum variant surface antigen expression varies between isolates causing severe and nonsevere malaria and is modified by acquired immunity. J Immunol 2002;168:3444-3450.

46. Jensen AT, Magistrado P, Sharp S, Joergensen L, Lavstsen T, Chiucchiuini A, Salanti A, Vestergaard LS, Lusingu JP, Hermsen R, Sauerwein R, Christensen J, Nielsen MA, Hviid L, Sutherland C, Staalsoe T, Theander TG. Plasmodium falciparum associated with severe childhood malaria preferentially expresses PfEMP1 encoded by group A var genes. J Exp Med 2004;199:1179-1190.

47. Kaestli M, Cockburn IA, Cortes A, Baea K, Rowe JA, Beck HP. Virulence of malaria is associated with differential expression of Plasmodium falciparum var gene subgroups in a case-control study. J Infect Dis 2006;193:1567-1574.

48. Kyriacou HM, Stone GN, Challis RJ, Raza A, Lyke KE, Thera MA, Kone AK, Doumbo OK, Plowe CV, Rowe JA.

Differential var gene transcription in Plasmodium falciparum isolates from patients with cerebral malaria compared to hyperparasitaemia. Mol Biochem Parasitol 2006;150:211-218.

49. Rottmann M, Lavstsen T, Mugasa JP, Kaestli M, Jensen AT, Muller D, Theander T, Beck HP. Differential expression of var gene groups is associated with morbidity caused by Plasmodium falciparum infection in Tanzanian children. Infect Immun 2006;74:3904-3911.

50. Taylor TE, Fu WJ, Carr RA, Whitten RO, Mueller JS, Fosiko NG, Lewallen S, Liomba NG, Molyneux ME. Differentiating the pathologies of cerebral malaria by postmortem parasite counts. Nat Med 2004;10:143-145.

51. Kraemer SM, Smith JD. Evidence for the importance of genetic structuring to the structural and functional specialization of the Plasmodium falciparum var gene family. Mol Microbiol 2003;50:1527-1538.

52. Lavstsen T, Salanti A, Jensen AT, Arnot DE, Theander TG. Sub-grouping of Plasmodium falciparum 3D7 var genes based on sequence analysis of coding and non-coding regions. Malar J 2003;2:27.

\section{Author Affiliations}

Fousseyni S. Touré, PhD

Centre International de Recherches

Médicales de Franceville (CIRMF)

BP 769 Franceville, Gabon

Odile Ouwe-Missi-Oukem-Boyer, PhD

Centre International de Recherches

Médicales de Franceville (CIRMF)

BP 769 Franceville, Gabon

Jérôme Mezui-Me-Ndong, MS

Centre International de Recherches

Médicales de Franceville (CIRMF)

BP 769 Franceville, Gabon
Guy Roger Ndong-Atome, PhD student

Centre International de Recherches

Médicales de Franceville (CIRMF)

BP 769 Franceville, Gabon

Ulrick Bisvigou, MD

Centre International de Recherches

Médicales de Franceville (CIRMF)

BP 769 Franceville, Gabon

Dominique Mazier, MD, PhD

Institut National de la Santé et de la

Recherche Médicale, U511, F-75013 Paris, France and

Université Pierre \& Marie Curie

Faculté de Médecine Pitié-Salpêtrière

F-75013 Paris, France

Sylvie Bisser, $M D, P h D$

Centre International de Recherches

Médicales de Franceville (CIRMF)

BP 769 Franceville, Gabon 